\title{
How College Business Students Learn With Emphasis On Differences Between Majors
}

\author{
Nikki Shoemaker, Stephen F. Austin State University, USA
}

Marie Kelly, Stephen F. Austin State University, USA

\begin{abstract}
Students' learning styles play an important role in their success in the classroom and beyond. This study explores the learning styles of business students so that professors can better understand the instructional methods that are most beneficial for their students. A survey of 205 business students in an introductory accounting course revealed that the most common learning style was visual, while the second most common learning style was kinesthetic. These results suggest that a large number of business students process and internalize new information best when they see or actively participate in what they are learning.
\end{abstract}

Keywords: Learning Styles; Business Students

\section{INTRODUCTION}

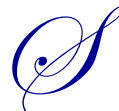

tudents' success in the classroom and beyond is dependent on their ability to learn the material they are being taught. While many factors influence a student's ability to learn, the student's learning style plays an important role (Dunn \& Griggs, 2000; Giordano \& Rochford, 2005; Zapalska \& Dabb, 2002). Learning style is defined as "the way in which each learner begins to concentrate on, process, and retain new and difficult information" (Dunn \& Dunn, 1993, p. 2). This concept and past research suggest that "individuals differ in regard to what mode of instruction or study is most effective for them" (Alexandra \& Moldovan, 2011, p. 578).

Previous research indicates that significant increases in student achievement occur when instructional approaches complement students' learning styles (Dunn \& Griggs, 2000; Giordano \& Rochford, 2005; Kastner \& Stangl, 2011; Zapalska \& Dabb, 2002). However, without understanding our students' learning styles, it is impossible for professors to teach in a way that complements these learning styles. Consequently, a mismatch between learning style and teaching style may exist, leading to poor academic achievement, low motivation, and a failure to learn (Kastner \& Stangl, 2011). The purpose of this study is to explore the learning styles of business students so that professors can better understand the instructional methods that are most beneficial for their students.

A survey of 205 business students in an introductory accounting course revealed that the most common learning style was visual. This suggests that a large number of business students process and internalize new information best when they see what they are learning. Visual learners benefit from receiving a variety of visual stimulants such as videos, PowerPoints, charts, and pictures (Vincent \& Ross, 2001; West Virginia Department of Education, 2012).

The second most common learning style was kinesthetic, which suggests that business students also learn best when they actively participate in their learning. Effective teaching strategies include providing students with hands-on activities, encouraging students to take notes, and making students physically move around the classroom (Vincent \& Ross, 2001).

In addition to discovering differences in learning styles among business students, supplemental analysis demonstrates distinctions between the different College of Business majors. Differences in learning style preferences relating to college majors is worth mentioning, as it merits modifications in teaching styles for instructors of the various business disciplines. 
Overall, the results of this study illustrate the importance of understanding students' learning styles in order to increase their learning success. The business students in the study had a variety of different preferences for learning new information, their working conditions, and how they express themselves. For teachers to facilitate success in the classroom and beyond, they should be aware of their students' learning style preferences. Such knowledge will allow them to ensure that their method of classroom instruction matches the learning styles of their students.

This study contributes toward the goal of achieving a match between student learning styles and instructors' teaching methods by investigating the learning style preferences of business students at a state university. While the results found here may not be wholly representative of business student population, they do reveal that students have a variety of learning styles, all of which should be addressed in an instructor's method of teaching.

The remainder of the paper is organized as follows. Section 2 further describes the learning style construct and describes the three categories of learning styles. Section 2 also discusses prior literature on learning styles and performance in the classroom. Section 3 describes the experimental methodology. Section 4 discusses the results of the study and Section 5 provides conclusions.

\section{LEARNING STYLE CONSTRUCT}

The concept that students learn new material in various ways is not a novel idea. As early as 2,300 years ago, Aristotle noted differences in the way children perceive and understand information. Modern educators recognize the fundamental dissimilarities in the way students comprehend new data and acquire additional knowledge. These distinctions have been labeled in contemporary society as individual learning styles.

One of the most widely used definitions characterizes learning styles as the cognitive, affective, and physiological behaviors that serve as indicators and determine how learners perceive, process, and respond to the learning environment (Alexandra \& Moldovan, 2011; Blakemore, McCray, \& Coker, 1984; Kirby \& Ashley, 1979; Zapalska \& Dabb, 2002). Learning style definitions have been modified by various authors including leading behavioral researchers Dunn and Dunn (1993), who stated, "learning style is the way students begin to concentrate on, process, internalize, and remember new and difficult academic information" (Giordano \& Rochford, 2005, p. 22). More recent definitions signify the direct impact that educators have on student understanding and acquiring of new knowledge through different forms of instruction. Kastner and Stangl (2011) propose that the educational conditions in which a student is most likely to learn is their preferred way of absorbing and retaining new information. Although it is evident that individuals have varying preferences regarding learning situations, effectiveness of the preferred educational environment must be measurable. Therefore, learning style "refers to the concept that individuals differ in regard to what mode of instruction or study is most effective for them" (Pashler et al., 2009, p. 105) with the concept that effectiveness can be assessed and is significant.

\section{MODELS AND PREFERENCES}

Determining a student's learning style is the first step towards evaluating the effectiveness of the instructional environment in the classroom. Several different models are designed to assess an individual's information processing preference, most of which are based on the five senses: sight, sound, touch, taste, and smell. The Learning Style Inventory (LSI) was originally developed by Dunn, Dunn, and Price in 1979. It is a broad, multidimensional model that tests learning conditions most appropriate for enhancement of specific learner comprehension (Dunn and Griggs, 2000). The five areas evaluated include environmental, emotional, sociological, physical, and psychological factors. Incorporated into the physical factors, besides time of day, mobility, and food, is "most importantly, whether information is presented verbally, in a written format, or in a hands-on approach in which tactile and kinesthetic senses can be used" (Blakemore et al., 1984, p. 41).

In a similar way, Canfield and Lafferty (1976) developed a Learning Styles Inventory which self-evaluated subjects based on four categories of information: Conditions, Content, Mode, and Expectation. Within the Mode category, individuals classified whether they preferred to learn new information through "Listening (hearing 
lectures, tapes, or speeches), Reading ( texts, pamphlets, or manuals), Iconic (looking at graphs, movies, or other visual material), or Direct Experience (handling materials to learn about them)" (Blakemore et al., 1984, p. 48). Both the Dunn, Dunn, and Price and the Canfield and Lafferty models (1976) recognize visual, listening, and tactile learning as requiring different comprehension processes.

An additional method to evaluate learning styles is the VARK model, which is an acronym for Visual, Aural, Read/Write, Kinesthetic (Fleming, 1995; Tennent, Becker, \& Kehoe, 2005). Visual learners retain new information better by seeing it, such as in charts, graphs, bulleted lists, or color-coded diagrams. Aural learners prefer to listen to acquire new information, such as traditional lectures, group discussions, Web chats, and even talking out loud to oneself. Read/Write students want unfamiliar material delivered to them in printed words, such as books, PowerPoint presentations, and Internet sources. The fourth type, kinesthetic learners, need movement and touch, when ascertaining further knowledge requires concrete personal experience, working practice examples, or real life simulations (Alexandra \& Moldovan, 2011; Jarmon, 2010; Tennent et al., 2005).

The C.I.T.E. (Center for Innovative Teaching Experiences) Learning Styles Inventory developed by Babich, Burdine, Albright, and Randol in 1976 utilizes these learning styles but combines the read/write group into the visual category. The C.I.T.E. survey tests three main areas: How students collect information, their preferred working conditions (by themselves or with a group), and how they express themselves (verbally or written) (Blakemore et al.,1984; Kastner \& Stangl, 2011). The first area dealing with the student preference for gathering information is defined as VAK (Visual, Auditory, and Kinesthetic), with each of these dimensions broken down further into several subcategories which will be described in the methodology section (Babich et al., 1976). The C.I.T.E. study illustrated how the different learning styles overlap in a majority of individuals, with a dominant style being the lead indicator of an individual's learning preference.

Recently, Sousa (1995) presents three primary learning styles as auditory, visual, and kinesthetic. Auditory students remember information better if they hear it, which helps them in a traditional school setting where teaching by lecture is common. However, only twenty percent of pupils are this type. Sousa (1995) states that the majority of students are visual learners who need a graphic model to visualize what they are trying to comprehend. Finally, kinesthetic learners comprehend best through touch, movement, field trips, simulations, and playing games (Sousa 1995, 1997; Zapalska \& Dabb, 2002).

The preponderance of learning styles research and evaluation models points to three broad categories of classification: Visual, Auditory, and Kinesthetic. Visual learners learn best when they can see the information. They learn best by seeing pictures or visual aids, reading written materials and, watching others (Kastner \& Stangl, 2011; Reid, 1987; Vincent \& Ross, 2001). Auditory learners must hear information to learn it. They prefer to talk with others about information, listen to explanations, and solve problems by talking through them (Reid, 1987; Vincent \& Ross, 2001). Kinesthetic learners need to learn by doing. They learn best when working on hands-on activities and becoming physically involved in their learning (Reid, 1987; Vincent \& Ross, 2001).

\section{TEACHING TO LEARNING STYLE IMPROVES PERFORMANCE}

The primary purpose of surveying students' learning styles is to modify the classroom environment in order to try to accommodate the various learning preferences. Regardless of which model is used, there is overall agreement among researchers that once students are aware of their particular styles, they will be able to use precise educational opportunities directed at their learning modalities. As students become attuned to their particular learning styles, they will begin to accommodate these methods in the classroom along with their individual study patterns outside the classroom. Matching learning styles with learning environment contributes significant benefits to learning outcomes (Fleming, 1995; Sadler-Smith, 1996; Schellens \& Valcke, 2000; Tennent et al., 2005; Vincent \& Ross, 2001).

Educators must be willing to adapt their teaching methods to support various types of learners beyond the minority auditory learning population. "People can grasp information quicker if they are provided with learning environments that enhance their learning preferences" (Kastner \& Stangl, 2011, p. 1). According to Dunn and Griggs (2000), numerous experimental studies conducted at 13 different universities suggest that accommodating 
learning styles is beneficial for academic achievement. When instructional strategies match students' learning styles, higher academic improvement is observed. This leads to the assumption that the worse students perform with traditional instruction, the better they will succeed when their learning styles are accommodated (Dunn \& Griggs, 2000).

\section{IMPROVED PERFORMANCE INFLUENCES RECALL AND RETENTION}

Educators continuously monitor student success through homework, quizzes, exams, projects, and innumerable assorted assignments in hopes that substantial amounts of information can be recalled and retained at some future date. The goal of recall and retention directly conflicts with the "brain dump" mentality used by many college students, where they cram for exams and forget the learned material immediately after turning in their tests.

If students are taught new and complex information through their highest learning preference, they will recall this knowledge significantly better than if the material was demonstrated using their least preferred learning choice (Giordano \& Rochford, 2005). For some instructors, this change in teaching direction may directly conflict with their own personal learning style. As Zapalska and Dabb (2002) stated, "Effective teaching arises when teachers reach those students who are mismatched with their own learning/teaching style" (p. 91). Therefore, instructors need to understand their personal learning style preference in order to deliver a mixture of instructional approaches to accommodate the various learning styles within their classrooms. Research has shown that modifying classroom instruction to match different learning styles will result in higher assessment scores, successful achievement, and effective recall and retention of additional information (Cook, 1991; Dunn, Bruno, Sklar, \& Beaudry, 1990; Mickler \& Zippert, 1987; Nelson et al., 1993; Rochford, 2003, 2004a, 2004b, 2004c; Williams, 1994).

\section{METHODOLOGY}

In this study, we use the C.I.T.E. Learning Styles Inventory discussed earlier (Babich et al., 1976). The inventory consists of 45 statements where students are asked to rank how they feel about each statement on a scale of 1 (least like them) to 4 (most like them). The C.I.T.E. Inventory was chosen for its appropriateness to the study and other practical considerations. Unlike other learning style inventories, the C.I.T. E. Inventory is fairly short, making it easier for students to complete without too much cognitive burden. Despite its shortness, the Inventory has been shown to have satisfying levels of reliability and validity (Babich \& Randol, 1984). The C.I.T.E. Inventory examines how students collect information, their preferred working conditions, and how they express themselves.

The first area dealing with the student preference for gathering information consists of five dimensions: visual-language, visual-numerical, auditory-language, auditory-numerical, and auditory/visual/kinesthetic (West Virginia Department of Education, 2012). Visual-language learners are those who learn well by seeing words. Visual-numerical students prefer to see numbers. Auditory-language learners learn best by hearing spoken words. Auditory-numerical students are those who learn by hearing numbers. Finally, auditory/visual/kinesthetic (Kinesthetic) students learn best through experience and involvement in the learning process.

The second area determines students' preferred working conditions and has two dimensions: socialindividual and social-group (West Virginia Department of Education, 2012). Social-individual students prefer to work alone, whereas social-group learners learn best when studying with at least one other student. The third area examines how students prefer to expressive themselves and consists of two dimensions: expressiveness-oral and expressiveness-written (West Virginia Department of Education, 2012). Expressiveness-oral students express themselves best by speaking to others and communicating what they know. Expressiveness-written learners prefer to express their knowledge by writing essays and answers on paper.

In this study, 205 students in five introductory accounting courses were surveyed. These courses consisted of students from various business disciplines, including management, marketing, accounting, economics, finance, and general business. Students were asked to fill out the C.I.T.E. Inventory without any prior class discussion of learning style preferences. Once the data was collected, students' primary and secondary learning style preferences were calculated following the form provided by Babich et al. (1976). 


\section{RESULTS}

Of the 205 students, 111 had more than one primary learning style. Overall, 125 students $(61.0 \%)$ were visual learners, with $102(49.8 \%)$ being visual-numerical learners and $80(39.0 \%)$ being visual-language learners. Some students were both visual-numerical and visual-language learners causing the individual percentages to add up to more than $61.0 \%$. Kinesthetic learners constituted $37.6 \%$ of the students surveyed. Meanwhile, only $32.7 \%$ were auditory learners (auditory-numerical $=25.4 \%$ plus auditory language $=11.7 \%$ minus overlap of students with both auditory-numerical and auditory-language $=4.4 \%$ ). Table 1 summarizes this information.

Table 1. Primary Learning Style Preferences

\begin{tabular}{lcc}
\hline \multicolumn{1}{c}{ Learning Style } & Number of Students & Percentage \\
\hline Visual Numerical (VN) & 102 & $49.8 \%$ \\
Visual Language (VL) & 80 & $39.0 \%$ \\
\hline Both VN \& VL & 57 & $27.8 \%$ \\
\hline Kinesthetic & 77 & $37.6 \%$ \\
Auditory Numerical (AN) & 52 & $25.4 \%$ \\
Auditory Language (AL) & 24 & $11.7 \%$ \\
\hline Both AN \& AL & 9 & $4.4 \%$ \\
\hline
\end{tabular}

Most of the student's (89.8\%) had an auditory secondary learning style preference, with $73.4 \%$ preferring auditory-language and $69.1 \%$ preferring auditory-numerical. Approximately $60 \%$ of students had a kinesthetic secondary learning style preference, whereas $70.2 \%$ had a visual secondary learning style preference. Table 2 summarizes this information.

Table 2. Secondary Learning Style Preferences

\begin{tabular}{lcc}
\hline \multicolumn{1}{c}{ Learning Style } & Number of Students & Percentage \\
\hline Auditory Language (AL) & 152 & $73.4 \%$ \\
Auditory Numerical (AN) & 143 & $69.1 \%$ \\
\hline Both AN \& AL & 111 & $54.1 \%$ \\
\hline Kinesthetic & 124 & $59.9 \%$ \\
Visual Language (VL) & 122 & $58.9 \%$ \\
Visual Numerical (VN) & 97 & $46.9 \%$ \\
\hline Both VN \& VL & 73 & $35.6 \%$ \\
\hline
\end{tabular}

The second area to consider is students' preferred working conditions. Of the 205 students surveyed, $95.1 \%$ had either a primary or secondary learning style preference to work alone, while $78.0 \%$ had either a primary or secondary learning style preference to work in groups. Of these, more students had a primary preference to work in groups than work individually ( $46.9 \%$ vs. $37.6 \%)$. Table 3 summarizes the specifics of students' working condition preferences.

Table 3. Working Condition Preferences

\begin{tabular}{lcc}
\hline & Number of Students & Percentage \\
\hline Social-Individual Learning Style & & $37.6 \%$ \\
\hline Primary Preference & 77 & $57.5 \%$ \\
Secondary Preference & 118 & $95.1 \%$ \\
Total & 195 & \\
\hline Social-Group Learning Style & & $46.9 \%$ \\
\hline Primary Preference & 97 & $35.6 \%$ \\
Secondary Preference & 73 & $78.0 \%$ \\
Total & 160 & \\
\hline
\end{tabular}

The final area to consider is students' preferred method of expressing themselves. Overall, $91.7 \%$ of the students had either a primary or secondary preference to express themselves in the written form, while $70.2 \%$ had either a primary or secondary preference to express themselves orally. Table 4 summarizes this information. 
Table 4. Expression Preferences

\begin{tabular}{lcc}
\hline & Number of Students & Percentage \\
\hline Expressiveness-Written Learning Style & & $12.7 \%$ \\
\hline Primary Preference & 26 & $79.0 \%$ \\
Secondary Preference & 162 & $91.7 \%$ \\
Total & 188 & $3.9 \%$ \\
\hline Expressiveness-Oral Learning Style & & $66.3 \%$ \\
Primary Preference & 8 & $70.2 \%$ \\
Secondary Preference & 136 & $14 \%$ \\
Total & 144 & \\
\hline
\end{tabular}

We performed additional analyses to explore potential differences in learning styles between College of Business majors, including accounting, economics, finance, general business, management, and marketing majors. The results are shown in Table 5.

Table 5. Primary Learning Style Preferences

\begin{tabular}{lccccccc}
\hline & \multicolumn{7}{c}{ Percentages (by major) } \\
\hline Learning Style & Total & Accounting & Economics & Finance & General Business & Management & Marketing \\
Visual Numerical (VN) & $49.8 \%$ & $47.1 \%$ & $44.4 \%$ & $\underline{\mathbf{6 6 . 7 \%}}$ & $\underline{\mathbf{6 1 . 1 \%}}$ & $41.0 \%$ & $\underline{\mathbf{6 0 . 7 \%}}$ \\
Visual Language (VL) & $39.0 \%$ & $42.1 \%$ & $33.3 \%$ & $41.7 \%$ & $33.3 \%$ & $43.6 \%$ & $46.4 \%$ \\
\hline \multicolumn{1}{c}{ Both VN \& VL } & $27.8 \%$ & $29.4 \%$ & $\mathbf{1 1 . 1 \%}$ & $33.3 \%$ & $30.6 \%$ & $\underline{\mathbf{3 9 . 3 \%}}$ \\
\hline Kinesthetic & $37.6 \%$ & $\mathbf{2 6 . 5 \%}$ & $44.4 \%$ & $25.0 \%$ & $33.3 \%$ & $\underline{\mathbf{4 8 . 7 \%}}$ & $46.4 \%$ \\
Auditory Numerical (AN) & $25.4 \%$ & $35.3 \%$ & $\mathbf{1 1 . 1 \%}$ & $25.0 \%$ & $27.8 \%$ & $\mathbf{1 5 . 4 \%}$ & $25.0 \%$ \\
Auditory Language (AL) & $11.7 \%$ & $17.6 \%$ & $11.1 \%$ & $16.7 \%$ & $13.9 \%$ & $10.3 \%$ & $0.0 \%$ \\
\hline \multicolumn{1}{c}{ Both AN \& AL } & $4.4 \%$ & $11.8 \%$ & $0.0 \%$ & $8.3 \%$ & $0.0 \%$ & $5.1 \%$ & $0.0 \%$ \\
\hline
\end{tabular}

Those majors whose learning style preferences were more than $10 \%$ higher than the overall average are indicated in bold in Table 5. Finance, general business, and marketing majors have a higher incidence of visual numerical learning styles. Marketing majors also have a higher occurrence of students who were both visual numerical and visual language learners. Finally, management majors have a higher frequency of kinesthetic learners.

Those majors whose learning style preferences were more than $10 \%$ lower than the overall average are italicized in Table 5. Economics majors have a lower incidence of students who have both a visual numerical and a visual language learning style. They also have a lower occurrence of students with an auditory numerical learning style. Accounting majors have a lower frequency of kinesthetic learners, while management majors have a lower frequency of auditory numerical learners.

These results suggest that some College of Business majors are more likely to have certain learning styles. For example, management majors are more likely to be kinesthetic learners than other College of Business majors. Similarly, marketing majors are more likely to be visual learners.

\section{CONCLUSION}

The purpose of this study was to explore the learning styles of business students so that professors can better understand the instructional methods that are most beneficial for their students. A survey of 205 business students suggests that the learning styles most preferred by business students are visual and kinesthetic learning styles. A large number of students had a secondary auditory learning style preference; however, secondary learning style preferences are not as effective as primary learning style preferences in helping students to process and learn new information (West Virginia Department of Education, 2012).

These results indicate that business students learn best when they can see the information they are learning and are actively involved in the learning process. For example, visual learners should be provided with pictures, charts, PowerPoints, and videos (Vincent \& Ross, 2001; West Virginia Department of Education, 2012). Kinesthetic learners should be given hands-on activities or activities that require them to physically move around the classroom (Vincent \& Ross, 2001). 
The results also suggest that the most prominent primary learning style preference for working conditions was to learn in groups. This indicates that business students should have the opportunity to interact with at least one other person during important times in the learning process (West Virginia Department of Education, 2012). Despite this result, a large number of students also preferred to work alone, indicating that the learning process should include opportunities to work both alone and in groups. The study also suggests that most students prefer to express themselves in the written form. Thus, students should be allowed to write reports and take written exams for evaluation purposes (West Virginia Department of Education, 2012).

Results from supplemental analysis indicate that different majors in the College of Business have a higher propensity for different learning styles. For example, marketing majors are more likely than other College of Business majors to be visual learners. Similarly, management majors are more likely to be kinesthetic learners, while accountants are less likely to be kinesthetic learners. These results suggest that instructors may choose to alter their teaching strategies when teaching courses designed specifically for one major.

Overall, this study illustrates that students' learn using a variety of sensory techniques. Consequently, to facilitate successful learning, professors should design their courses to address the various different learning style preferences. By using an assortment of teaching methods, students will have the best chance to recall, retain, and understand the information presented to them in their courses.

\section{AUTHOR INFORMATION}

Nikki Shoemaker joined Stephen F. Austin State University (SFA) in August 2012. Her primary research is in the area of management control systems. Specifically, Dr. Shoemaker specializes in the joint influence of compensation and monitoring systems on employee behavior. Her primary teaching interest includes managerial accounting. Before coming to SFA, she taught at the University of North Texas and worked as the Risk and Compliance Auditor at SFA. (Contact author) E-mail shoemakenl@sfasu.edu

Marie Kelly taught as a lecturer in the Accounting Department from 1987-1991. From 2006-2010, she was an adjunct faculty member before returning to the department full-time. She received her CPA license in 1984. Prior to joining SFA in 1987, she worked for five years in public accounting and private industry in Houston, Lufkin, and Nacogdoches. She is active in the Texas Society of CPA's and the East Texas Chapter of CPA's. E-mail: kellymarie@sfasu.edu

\section{REFERENCES}

Alexandra, M., \& Moldovan, G. (2011). How to better meet our students' learning style through the course resources. Annals of the University of Oradea: Economic Science, 1, 578-585.

Babich, A. M., Burdine, P., Albright, L. \& Randol, P. (1976). C. I. T. E. Learning Styles Inventory. Wichita, KS: Murdock Teacher Center.

Babich, A. M., \& Randol, P. (1984). C. I. T. E. Learning Styles Inventory reliability report. Wichita, KS: Murdock Teacher Center.

Blakemore, T. F., McCray, P. M., \& Coker, C. (1984). A guide to learning style assessment. Menomonie, WI: University of Wisconsin-Stout, Stout Vocational Rehabilitation Institute, Research and Training Center.

Canfield, A. A., \& Lafferty, J. C. (1976). Learning Styles Inventory. Detroit, MI: Humanics Media.

Cook, L. (1991). Learning-style awareness and academic achievement among community college students. Community Junior College Quarterly of Research and Practice, 16, 419-425.

Dunn, R., Bruno, J., Sklar, R., \& Beaudry, J. S. (1990). The effects of matching and mismatching minority developmental college students' hemispheric preferences on mathematics test scores. Journal of Educational Research, 83, 283-288.

Dunn, R., Dunn, K., \& Price, G. E. (1979). Learning Styles Inventory. Lawrence, KS: Price Systems.

Dunn, R., \& Dunn, K. (1993). Teaching secondary students through their individual learning styles: Practical approaches for grades 7-12. Boston, MA: Allyn and Bacon.

Dunn, R., \& Griggs, S. A. (2000). Practical approaches to using learning styles in higher education. Westport, CT: Bergin and Garvey. 
Fleming, N. D. (1995). I'm different; not dumb. Modes of presentation (VARK) in the tertiary classroom. In the Proceedings of the 1995 Annual Conference of the Higher Education and Research Development Society of Australia, 18, 308-313.

Giordano, J., \& Rochford, R. (2005). Understanding business majors' learning styles. Community College Enterprise, 11, 21-39.

Jarmon, A. L. (2010). How to absorb information to make it more memorable. Student Law, 39, $22-24$.

Kastner, M., \& Stangl, B. (2011). Mapping learning aids and introducing learning styles as a moderator. Proceedings of the $44^{\text {th }}$ Hawaii International Conference on System Sciences, 1-10.

Kirby, P., \& Ashley, W. L. (1979). Cognitive style, learning style, and transfer skill acquisition. Columbus, OH: National Center for Research in Vocational Education, Ohio State University.

Mickler, M., \& Zippert, C. (1987). Teaching strategies based on learning styles of adult students. Community/Junior College Quarterly, 11, 33-37.

Nelson, B., Dunn, R., Griggs, S. A., Primavera, L., Fitzpatrick, M., \& Bacillious, Z. (1993). Effects of learning-style intervention on college students' retention and achievement. Journal of College Student Development, 34 , 364-369.

Pashler H., McDaniel, M., Rohrer, D., \& Bjork, R. (2009). Learning styles, concepts and evidence. Psychological Science in the Public Interest, 9, 105-119.

Reid, J. M. (1987). The learning style preferences of ESL students. TESOL Quarterly, 21, 87-110.

Rochford, R. A. (2003). Assessing learning styles to improve the quality of performance of students in developmental writing programs at an urban community college. Community College Journal of Research and Practice, 27, 665-677.

Rochford, R. A. (2004a). Effects of learning-style responsive materials on underachieving remedial-writing students at an urban community college. Dissertation Abstracts International, 64, 4329.

Rochford, R. A. (2004b). Helping ESL students get their acts together: Preparing students for the ACT writing skills test. Community Review, 18, 19-27.

Rochford, R. A. (2004c). Improving academic performance and retention among remedial students. Community College Enterprise, 10, 23-36.

Sadler-Smith, E. (1996). Learning styles: A holistic approach. Journal of European Industrial Training, 20, 29-36.

Schellens, T., \& Valcke, M. (2000). Re-engineering conventional university education: Implications for students' learning styles. Distance Education, 21, 361-384.

Sousa, D. (1995). How the brain learns. Reston, VA: National Association of Secondary School Principals.

Sousa, D. (1997). How the brain learns: New insights into the teaching/learning process. Reston, VA: National Association of Secondary School Principals.

Tennent, B., Becker, K. L., \& Kehoe, J. (2005). Technology-enabled delivery and assessment methods: Are we addressing student expectations and learning preferences? Proceedings of the Australasian Society for Computers in Learning in Tertiary Education, 649-659.

Vincent, A., \& Ross, D. (2001). Personalize training: Determine learning styles, personality types and multiple intelligences online. The Learning Organization, 8, 36-43.

Williams, H. S. (1994). The differences in cumulative grade-point averages among African-American freshman college learning styles: A preliminary investigation. National Forum of Applied Educational Research Journal, 8, 36-40.

West Virginia Department of Education. (2012). WVABE instructor handbook. Retrieved from http://wvde.state.wv.us/abe/tcher_handbook_pdf/

Zapalska, A. M., \& Dabb, H. (2002). Learning styles. Journal of Teaching in International Business, $13,77-97$. 